\title{
DIALOGANDO COM AS LÍNGUAS SELVAGENS: CONTRIBUIÇÕES DE GLORIA ANZALDÚA PARA PENSAR O FEMINISMO DECOLONIAL
}

\author{
DIALOGGING WITH THE WILD LANGUAGES: GLORIA ANZALDÚA'S CONTRIBUTIONS TO THINKING ABOUT \\ DECOLONIAL FEMINISM
}

\section{RESUMO}

A decolonialidade é uma proposta epistemológica construída a partir da obra de Aníbal Quijano (1930-2018), que busca romper com a colonialidade imposta às sociedades colonizadas, de maneira a criar e manter hierarquizações e classificações subalternizantes. Diversas teóricas feministas levaram essa perspectiva teórica para o campo feminista, forjando o que podemos denominar de feminismo decolonial. Sua proposta central é construir uma agenda feminista focada nas vozes e nas experiências das mulheres situadas ao Sul, nas sociedades que sofreram intrusões coloniais. Nessa perspectiva, a proposta do presente artigo é estabelecer um diálogo entre o feminismo decolonial e a teórica chicana Gloria Anzaldúa (1942-2004), considerada um dos expoentes do feminismo descolonizado.

Palavras-chave: Gloria Anzaldúa. Decolonialidade. Feminismo decolonial. Norte. Sul. Línguas selvagens

\begin{abstract}
Decoloniality is an epistemological proposal built on the work of Aníbal Quijano (1930-2018) that seeks to break with the coloniality imposed on colonized societies, in order to create and maintain subordinate hierarchies and classifications. Several feminist theorists have taken this theoretical perspective to the feminist field, forging what we might call decolonial feminism. Its central proposal is to build a feminist agenda focused on the voices and experiences of women located in the South, in societies that have suffered colonial intrusions. In this perspective, the purpose of this article is to establish a dialogue between decolonial feminism and the Chicana theorist Gloria Anzaldúa (1942-2004), considered one of the exponents of decolonized feminism.
\end{abstract}

Keywords: Gloria Anzaldúa. Decoloniality. Decolonial feminism. North. South. Wild languages

Vivian da Veiga Silva

Doutora em História pela Universidade Federal da Grande Dourados. Professora adjunta da Universidade Federal de Mato Grosso do Sul/Campus do Pantanal. E-mail: vivian.veiga@ufms.br 


\section{Introdução}

Na contemporaneidade, percebemos a proliferação de vozes e de escrituras que buscam pensar o mundo a partir do exercício da descolonização, de maneira a superar a lógica colonial instaurada nas mais diversas áreas e nos mais diversos setores, incluindo aí o feminismo. Nessa perspectiva, consideramos de suma importância resgatar as vozes subalternas que já se insurgiam contra a colonialidade em outros períodos históricos. No presente artigo, propomos dialogar com a obra da escritora e teórica cultural chicana Gloria Anzaldúa (1942-2004), que de maneira versátil, publicou poesias, ensaios teóricos, contos e narrativas autobiográficas, além de atuar como editora e coautora de três antologias multiculturais. Estadunidense de origem mexicana e assumidamente lésbica, buscou incessantemente, através de sua escrita e de seu ativismo, redefinir as identidades chicana, lésbica e queer, ressignificando, de maneira descolonizada, esses marcadores identitários.

Anzaldúa nasceu no Vale do Rio Grande, no sul do Texas, em uma família de trabalhadores rurais migrantes que, por gerações, viveram nessa região. Para garantir acesso à escola, seus pais se mudaram para a cidade de Hargill, onde Anzaldúa se deparou com o que ela denominou de "terrorismo linguístico": a imposição de cursos de dicção para a eliminação de seu sotaque mexicano. Com a morte de seu pai, aos 14 anos, Anzaldúa foi obrigada a ajudar financeiramente a família, trabalhando no campo, enquanto cursava educação básica e secundária. Enfrentou diversos obstáculos para obter a licenciatura em Arte e Literatura na Universidade Pan American, em 1969; posteriormente concluiu o mestrado na Universidade do Texas, em Austin. Ministrou cursos sobre feminismo, estudos chicanos e escrita criativa em várias universidades norte-americanas. Faleceu em maio de 2004.

Com sua escrita desafiadora e sensível, a autora e ativista nos convida a fugir de perspectivas e teorias engessadas e coloniais, para alcançar categorias e conceitos que contemplem a experiência e a vivência de sujeitos subalternos e silenciados. Da mesma forma, Anzaldúa contesta o denominado feminismo hegemônico, que somente contempla as demandas das mulheres brancas e eurocentradas e que enxerga as mulheres não-brancas (negras, latinas, asiáticas) a partir de uma lógica salvacionista e sem voz para construir suas próprias reivindicações. A obra de Anzaldúa nos proporciona uma ampla reflexão sobre a potencialidade da consciência mestiça (uma nova compreensão sobre os sujeitos híbridos e fronteiriços) e para a reconstrução do conhecimento e do feminismo.

Exposto isso, propomos para o presente artigo uma reflexão sobre as contribuições de Gloria Anzaldúa para pensarmos e construirmos um feminismo decolonial. Partindo dos textos da autora chicana, buscaremos elementos que podem ser utilizados para fortalecer essa nova forma de fazer o feminismo, de maneira a se afastar definitivamente das práticas coloniais do feminismo hegemônico. Num primeiro momento, discutiremos a noção de colonialidade elaborada por Aníbal 
Quijano, para em seguida alcançarmos os diálogos que as feministas decoloniais (aqui citamos Rita Segato, María Lugones, Karina Bidaseca e Luciana Ballestrin) estabelecem com o autor para a construção de um novo paradigma feminista. Por fim, estabeleceremos um diálogo do feminismo decolonial com a obra de Anzaldúa, buscando possíveis elementos para fortalecimento dessa vertente feminista. Para tanto, utilizaremos os seguintes textos de sua autoria: Borderland/La frontera: la nueva mestiza (originalmente publicado em 1987), no qual a autora combina história e narrativa pessoal para examinar a condição de mulher chicana e lésbica, assim como o isolamento da vivência nas mais diversas fronteiras; La prieta e Hablar em lenguas: una carta a escritoras tercermundistas, que compõem o livro Este puente mi espalda (originalmente publicado em 1981), um compilado de artigos de feministas terceiro-mundistas editado por Cherríe Moraga e Ana Castillo.

\section{Decolonialidade e feminismo}

A concepção de decolonialidade foi construída a partir da obra do sociólogo peruano Aníbal Quijano (1930-2018). Para o autor (2009), o poder das sociedades eurocentradas sobre as sociedades colonizadas não cessa com o fim do colonialismo, sendo essa lógica substituída pelo que ele denomina de colonialidade:

A colonialidade é um dos elementos constitutivos e específicos do padrão mundial de poder capitalista. Sustenta-se na imposição de uma classificação racial/étnica da população do mundo como pedra angular do referido padrão de poder e opera em cada um dos planos, meios e dimensões, materiais e subjectivos, da existência social quotidiana e da escala societal. Origina-se e mundializa-se a partir da América. (QUIJANO, 2009: 73)

Quijano (2009) entende que as sociedades colonizadas são organizadas e regidas a partir da lógica da colonialidade do poder, fazendo com que essas criem e mantenham hierarquizações de raça/etnia que estarão estreitamente ligadas às formas de exploração do trabalho. Dessa forma, a colonialidade do poder ainda atua na contemporaneidade como um sistema estruturador mundial, conforme indica Ballestrin (2013: n.p):

A expressão "colonialidade do poder" designa um processo fundamental de estruturação do sistema-mundo moderno/ colonial, quearticula os lugares periféricos da divisão internacional do trabalho com a hierarquia étnico-racial global e com a inscrição de migrantes do Terceiro Mundo na hierarquia étnico-racial das cidades metropolitanas globais [...] 
A autora ainda salienta que a noção de raça funciona como um princípio organizador das hierarquias do sistema-mundo. A colonialidade do poder organiza o sistema-mundo a partir da hierarquização racial das sociedades, cabendo a essas o papel de dominador/colonizador (sujeitos brancos eurocêntricos) ou o papel de dominado/colonizado (sujeitos não-brancos, subalternizados e silenciados). A distribuição de poder e de recursos também obedecerá a lógica da colonialidade, fazendo com que as sociedades que sofreram as intrusões coloniais ainda permaneçam sob a dominação dos colonizadores mesmo na contemporaneidade.

Para Lugones (2014), a colonialidade não somente cria as hierarquizações raciais, como determina a separação entre humanos (homens e mulheres brancos europeus) e não-humanos (machos e fêmeas colonizados):

Ao usar o termo colonialidade, minha intenção é nomear não somente uma classificação de povos em termos de colonialidade de poder e de gênero, mas também o processo de redução ativa das pessoas, a desumanização que as torna aptas para a classificação, o processo de sujeitificação e a investida de tornar o/a colonizado/a menos que seres humanos [...] (LUGONES, 2014: 939).

Nessa perspectiva, autores e autoras da América Latina passaram a pensar a construção do poder e do saber a partir da perspectiva de Quijano, de maneira a buscar a descolonização dos processos sociais, culturais, políticos e teóricos, denominando esse movimento de decolonialidade ou giro decolonial. De acordo com Ballestrin (2013: n.p), trata-se de um "[...] movimento de resistência teórico e prático, político e epistemológico, à lógica da "modernidade/colonialidade". Dessa forma, a decolonialidade é o exercício de construir formas de pensar e de compreender o mundo a partir da experiência e da vivência em uma sociedade de passado colonial, de maneira a construir perspectivas e paradigmas próprios e que não remeta aos saberes construídos e impostos pelos colonizadores. Segundo a autora (2013: n.p),

[...] Se toda teoria serve para algo ou para alguém, é razoável partir do princípio de que ela produz relações de colonialidade do próprio poder. Historicamente, a teoria e a filosofia política foram predominantemente pensadas no Norte e para o Norte. Por um lado, ela serviu como pilar fundamental para a arquitetura de exploração, dominação e colonização dos povos são situados no Ocidente exemplar [...]

Com isso, compreendemos que a decolonialidade é o fazer teórico e político de maneira a escapar da colonialidade do poder; um exercício de pensamento que recusa o domínio teórico do Norte eurocentrado e que se constrói sob as premissas 
do Sul' ${ }^{1}$, utilizando para isso suas vivências, suas experiências, suas aprendizagens. Tudo isso coloca-se como uma estratégia para romper com o domínio e a subjugação colonial, construindo um novo imaginário social e um novo campo teórico liberto das premissas impostas pelo Norte. Esse novo paradigma de contestação e de resistência à colonialidade se estendeu para diversos campos, dentre eles, o feminismo.

Para Mohanty (2008), a construção de um feminismo das mulheres terceiromundistas requer compulsoriamente a crítica e a desconstrução do feminismo hegemônico:

Cualquier discusión sobre la construcción intelectual y política de los "feminismos del tercer mundo" debe tratar dos proyectos simultâneos: la critica interna de los feminismos hegemónicos de "Occidente", y la formulación de interes y estrategias feministas basados en la autonomia, geografia, historia y cultura. El primero es un proyecto de deconstrucción y desmantelamento; el segundo, de construcción y creación. Estos proyectos - el primero funcionando de forma negativa y el segundo de forma positiva - parecen contradictorios, pero a menos que sus labores respectivas se aborden de forma simultânea, los feminismos del "tercer mundo" corren el riesgo de verse marginados y ghettizados tanto en las tendências principales (de derecha e izquierda) del discurso feminista como en el discurso feminista de occidente. (MOHANTY, 2008: 112)

A partir do aporte teórico construído por Quijano, autoras feministas passaram a construir uma nova perspectiva para o feminismo, estabelecendo um diálogo entre esse campo e a decolonialidade, assim como elaborando uma crítica contundente ao feminismo hegemônico. Dessa forma, é possível pensarmos um feminismo decolonial, que se afasta do feminismo hegemônico e eurocentrado e constrói suas premissas a partir das pautas, das demandas e das reflexões das mulheres que habitam o Sul e que são advindas de sociedades que sofreram com as intrusões coloniais.

Podemos então compreender o feminismo decolonial como um movimento que reconhece a especificidade das mulheres que habitam as sociedades atravessadas pelo colonialismo e pela colonialidade. Remetendo a Bidaseca (2011), trata-se de quebrar o monopólio das vozes hegemônicas e colonizadoras, retirando do silêncio colonial as mulheres que são representadas por outras vozes que não as delas. Trata-se de reconhecer que o movimento feminista pode ser colonizador ao negar a visibilidade e a voz às mulheres não-brancas e colonizadas, em uma tentativa de falar por elas e de representá-las, negando a elas o protagonismo das suas pautas e das

1 De acordo com Bidaseca (2018:17), o Sul não é necessariamente uma posição geográfica, mas sobretudo uma postura anticolonial: "Cuando me refiero al "Sur" no es en sentido geográfico sino geopolítico. El Sur es heterogéneo. Hay múltiples sures (en efecto, hay sures en el norte), com proyectos políticos anticapitalistas, anti-racistas, anti-sexistas [...]" 
suas demandas. Nessa perspectiva, trazemos as ideias construídas por cinco autoras feministas decoloniais acerca dessa forma de fazer e pensar o feminismo.

Dialogando constantemente com Quijano, Segato (2016) aponta para a existência de um patriarcado ${ }^{2}$ de baixa intensidade nas sociedades pré-intrusão, sendo que essa estrutura política é agudizada pelos processos coloniais, estabelecendo o que a autora denomina de patriarcal-colonial-modernidade.

[...] la superinflación de los hombres en el ambiente comunitário, en su papel de intermediário con el mundo exterior, es decir, con la administración del blanco; la emasculación de los hombres en el ambiente extracomunitário, frente al poder de los administradores blanco; la superinflación y universalización de la esfera pública, habitada ancestralmente por los hombres, con el derrumbe y privatización de la esfera doméstica; y la binarización de la dualidad, resultante de la universalización de uno de sus dos términos, constituído como público, en oposición a outro, constituído como privado. (SEGATO, 2016: 113)

Diante desse processo, Segato (2016) aponta para uma minorização das mulheres e uma caída abrupta do valor e da politicidade do espaço doméstico, constituindo o corpo feminino na primeira colônia. Logo, faz-se necessário compreender os processos históricos que levaram as mulheres ao lugar de minoria e sujeito subalternizado, fazendo emergir as práticas e os discursos da colonialidade de gênero que se impõem violentamente contra os corpos femininos. Somente a partir desse processo de desconstrução é possível alcançarmos a possibilidade de estabelecermos uma visão descolonizada acerca das mulheres pertencentes às sociedades que sofreram as intrusões coloniais, assim como explicitar as violências e os silenciamentos impostos a esses sujeitos.

Ainda dialogando com Quijano, Lugones (2014) afirma que a modernidade colonial se firma a partir da dicotomia entre humano (colonizador) e não-humano (colonizado), sendo incapaz de pensar toda a heterogeneidade e a diversidade que existe para além das categorias dicotômicas:

A modernidade organiza o mundo ontologicamente em termos de categorias homogêneas, atômicas, separáveis. A crítica contemporânea ao universalismo feminista feita por mulheres de cor e do terceiro mundo centra-se na reivindicação de que a intersecção entre raça, classe, sexualidade e gênero vai além das categorias da modernidade. Se mulher e negro são termos para categorias homogêneas, atomizadas e separáveis, então sua intersecção mostra-nos a ausência das mulheres negras - e não

2 Segato (2016) compreende o patriarcado como uma estrutura política arcaica e com ampla duração histórica baseada na desigualdade entre homens e mulheres. 
sua presença. Assim, ver mulheres não-brancas é ir além da lógica “categorial” [...] (LUGONES, 2014: 935)

Nessa perspectiva, a autora denuncia que, a partir da ação da colonialidade de gênero (sendo essa entendida como a análise da opressão de gênero racializada e capitalista), a categoria "mulher colonizada" é completamente vazia, visto que a categoria "mulher" foi construída a partir das representações sociais acerca das fêmeas brancas e eurocentradas, sendo que essa construção não é transponível para as fêmeas dos povos colonizados. Logo, para fazermos emergir, de fato, as mulheres colonizadas e subalternizadas, enquanto corpos e sujeitos, faz-se necessário descolonizar as noções de mulher e de gênero: "Descolonizar o gênero é necessariamente uma práxis. É decretar uma crítica da opressão de gênero racializada, colonial e capitalista heterossexualizada visando uma transformação vivida do social [...]” (LUGONES, 2014: 940).

Para Lugones, esse movimento somente é possível a partir de uma descolonização do feminismo:

[...] a tarefa da feminista descolonial inicia-se com ela vendo a diferença colonial e enfaticamente resistindo ao seu próprio hábito epistemológico de apagá-la. Ao vê-la, ela vê o mundo renovado e então exige de si mesma largar seu encantamento com "mulher", o universal, para começar a aprender sobre as outras que resistem à diferença colonial. [...] (LUGONES, 2014: 948)

Portanto, trata-se de um exercício político e epistemológico de desconstruir as categorias coloniais e reconstruí-las de maneira a inserir as vivências e as experiências das mulheres colonizadas, superando o sentido universalista da categoria mulher e enervando-a com a diferença e a diversidade colonial. Nesse sentido, para Bidaseca e Vazquez (2010), é fundamental elaborar uma crítica ao feminismo hegemônico ocidental por este atuar de maneira universalizante e etnocêntrica, desconsiderando o conhecimento das sociedades ao Sul.

En general, las teorias feministas blancas hegemónicas interpretan las prácticas culturales de las mujeres subalternas como resíduos arcaicos; las representan como inmaduras para la praxis política y, por tanto justifican la necesidad de ser "educadas" em el feminismo occidental. (BIDASECA; VAZQUEZ, 2010: n.p)

As autoras indicam que o feminismo hegemônico adota uma retórica salvacionista em relação às mulheres não-brancas, desprezando as diferenças e a diversidade de suas vivências e de suas experiências. Dessa forma, é imprescindível construir e fortalecer um feminismo que seja próprio dessas mulheres e que escape das representações construídas pelos sujeitos eurocentrados. Somente a partir desse 
movimento é possível superar a colonialidade de gênero que se estabeleceu com relação às mulheres pertencentes às sociedades colonizadas.

[...] Para nosotras se trata de complejizar este pensamento tomando al género como objeto de análisis y así construir un pensamento que parta del borde entre la episteme occidental y las epistemes de los pueblos colonizados, e instale a América Latina y los llamados países del Tercer Mundo como lugares legítimos de enunciación no pretendidamente universales. (BIDASECA; VAZQUEZ, 2010: n.p).

Trata-se de um esforço teórico e político de construir uma prática e um saber feminista descolonizados, libertos das premissas hegemônicas impostas pelos feminismos eurocentrados. Mas não é somente isso: o feminismo decolonial é um exercício de situar a construção de uma agenda feminista a partir das especificidades das mulheres latino-americanas e terceiro-mundistas, proporcionando um giro epistemológico dentro da teoria feminista. Para Ballestrin (2017),

A proposta de um feminismo decolonial, apesar de envolver certa descolonização do feminismo, não pode ser considerada seu sinônimo. Por parte de suas autoras entusiastas, existe uma clara tentativa de marcar sua distinção dos feminismos outros. Essa distinção dá-se por filiação teórica, influência e geografia. À semelhança de certas estratégias discursivas, retóricas e teóricas decoloniais, o feminismo decolonial faz questão de colocar as Américas e a América Latina, em particular, como mapa de sua referência. Vincula-se epistemologicamente com o grupo Modernidade/Colonialidade. (BALLESTRIN, 2017: 1044)

Com isso, a autora compreende que o fazer do feminismo decolonial se trata de uma intervenção teórica sobre a ideia de gênero a partir das ideias de Quijano, de maneira a dar voz e visibilidade para as mulheres latino-americanas, não-brancas, negras, chicanas e indígenas. O feminismo decolonial (também chamado por Balllestrin de feminismos do Sul) constrói-se a partir da quebra da lógica colonial, que somente confere legitimidade ao feminismo hegemônico e que não reconhece a possibilidade de protagonismo das mulheres colonizadas. A decolonialidade permite a essas mulheres pensar e executar um feminismo centrado a partir de suas vivências e de suas experiências, dando voz aos seus anseios e às suas demandas, sem nenhum tipo de porta-voz ou tradutor. 


\section{O que as línguas selvagens têm a dizer? A voz da nueva mestiza}

Gloria Anzaldúa emergiu, entre as décadas de 1970 e 1980, como uma importante teórica e ativista no chamado feminismo da inclusão, que buscava construir uma vertente feminista a partir das experiências e das vivências das mulheres de cor e terceiro-mundistas. A autora trabalhou arduamente para reconstruir categorias como fronteira e identidade, pensadas de maneira monolítica e que não contemplavam o hibridismo e a instabilidade da condição de mestiça e fronteiriça. O pensamento hegemônico enxerga tudo de maneira unilateral e engessado, excluindo a diversidade, o múltiplo e o diferente. A luta de Anzaldúa é justamente por uma teoria, por uma militância e por uma escrita que permitam aos sujeitos múltiplos e diversos se expressarem sem preconceitos e exclusões, garantindo a voz daqueles e daquelas que são subalternizados e subalternizadas pelo pensamento hegemônico.

Fazendo uma aproximação de Anzaldúa com a ideia de decolonialidade, remetemos à afirmação anterior de que o Sul não é uma posição geográfica, mas sim geopolítica. Embora a autora estivesse geograficamente no Norte (ela era estadunidense de ascendência mexicana, considerava-se chicana), sua voz clamava pelas demandas do Sul, para que essas mulheres subalternizadas e colonizadas, fossem ouvidas e tivessem garantido o direito a falar por si mesmas, a se articularem em movimentos próprios e a lutarem por suas expectativas sem a interferência das mulheres eurocentradas. Dessa forma, podemos pensar na proximidade de Anzaldúa em relação aos objetivos e às reflexões do feminismo decolonial.

Para esse exercício de estabelecer diálogo entre a autora e o feminismo decolonial, destacaremos elementos da obra de Anzaldúa que nos permitam pensar a crítica ao feminismo hegemônico, assim como contribuições para a decolonialidade e o feminismo decolonial. Também é possível pensarmos a relação de Anzaldúa com a teoria das vozes elaborada por Karina Bidaseca (2010), visto que ela se coloca como uma voz baixa e subalterna (chicana e lésbica nos Estados Unidos) que se levanta, se rebela e conclama outras vozes a se levantarem.

De acordo com Bidaseca (2010), a voz deve ser compreendida como um instrumento de agenciamento. De acordo com a autora,

Luego comprendí que, como la mirada, la voz es efecto de poder. Las voces bajas que escuchaba en los viajes al "interior" fueron marcadas por la colonialidad y el rol de la violência estructural en el capitalismo. La modernidad y la monoglosia del colonizador condenaron a la población colonizada a ser cuerpos invisibles, mestizados, y voces bajas. Al contrario, las voces que llamo "altas" son las que organizan y controlan el campo sonoro y por ello detentanelpoder de hablarpor...Ello me hállevadoalconvencimento de que las voces omnipresentes son significativas en tanto operan em la realidad y pueden transformala. Por certo, hay determinados 
mecanismos por los cuales las voces se conducen hasta llegar (no siempre, por supuesto) a alcanzar un lugar de enunciación y dejar de ser, como explica Spivak, subalternas. Hay voces que no lo logran, pues quedan atrapadas en el laberinto sonírico de las voces de otros. Que reproducen las voces de los otros. Que no pueden autonomizarse de ellas. Que emiten meramente ruidos. $Y$ ello conduce, certeramente, a uma complicidad em la reprodución del orden social. (BIDASECA, 2010: 198)

Partindo da perspectiva de que os sujeitos que detêm o poder são aqueles e aquelas autorizados e autorizadas a falarem e a serem ouvidos e ouvidas, Bidaseca divide o campo social entre as vozes altas (ou seja, as vozes hegemônicas, que são mais audíveis) e as vozes baixas (não-hegemônicas e pouco audíveis). A autora fala em um colonialismo discursivo, visto que os predicados de alta ou baixa são determinados pelas forças da colonialidade, hierarquizando colonizadores (vozes altas) e colonizados (vozes baixas). Ainda de acordo com Bidaseca (2010), a forma mais efetiva de garantir a superação da subalternização e da colonialidade é alcançar a potência discursiva e tornar-se audível no campo social.

Em seus escritos, Anzaldúa aponta para a existência dessa separação entre vozes altas e vozes baixas, indicando que as vozes das mulheres não-brancas e terceiro-mundistas são silenciadas na sociedade e até mesmo dentro do movimento feminista, que se coloca enquanto hegemônico e eurocentrado. Para a autora, as mulheres subalternizadas devem assumir a potência de suas existências e tornaremse audíveis dentro do campo social. Sobre essa discussão, destacamos elementos do texto Hablar en lenguas: una carta a escritoras tercermundistas (1988), publicado na antologia Este puente, mi espalda, no qual Anzaldúa elabora uma crítica ao feminismo hegemônico e conclama as mulheres terceiro-mundistas a levantarem suas vozes.

O texto citado é uma carta redigida por Anzaldúa e direcionada às mulheres de cor, a quem ela chama de "companheiras de escritura" e as convoca a fim de que utilizem a escrita como um ato de rebelião.

La mujer tercermundista se rebela: Cancelamos, borramos tu señal de hombre blanco. Cuando vengas a tocar nuestras puertas con tus estampas de goma para marcarnos la cara con TONTA, HISTERICA, PASIVA, PUTA, PERVERSA, cuando vengas con tu hierro de manear para quemar MI PROPIEDAD en nuestras nalgas, vomitaremos en tu boca la culpa, la abnegación y el odio de la raza que nos has forzado a comer. Acabamos de ser cojines para tus temores proyectados. Estamos cansadas de ser tus cordeiros sacrificatorios y chivos expiatorios. (ANZALDÚA, 1988: 222)

Esse ato de rebelião conclamado por Anzaldúa não se aplica somente aos preconceitos e silenciamentos impostos pelos homens brancos, mas também às mulheres brancas que contribuem para a exclusão das mulheres não-brancas e 
terceiro-mundistas, adotando uma postura salvacionista, não permitindo que elas sejam visibilizadas. Sobre o feminismo branco e hegemônico, a autora argumenta:

No es probable ser amigas de gente literaria en lugares altos, la principiante de color es invisible en el mundo principal del hombre blanco y en el mundo feminista de las mujeres blancas, aunque en éste hay câmbios graduales. La lesbiana de color no sólo es invisible, ni siquiera existe. Nuestro lenguage, también, es inaudible. Hablamos en lenguas como las repudiadas y locas. (ANZALDÚA, 1988: 220)

Com isso, Anzaldúa nos traz a ideia de que as mulheres não-brancas e terceiro-mundistas falam uma língua inaudível, considerada selvagem pelas vozes hegemônicas. O repúdio a essa língua e a essas vozes levam as mulheres subalternizadas a um processo de invisibilização e de silenciamento. Todos esses aspectos se repetem mesmo nos lugares onde deveria haver a crítica, como é o caso do movimento feminista hegemônico, que adotava uma postura colonizadora em relação às mulheres não-brancas e terceiro-mundistas.

[...] Sus discípulas son notorias por "adoptar" a mujeres de color como "causa" mientras aun esperan que nosotras nos adaptemos a sus expectativas y a su lenguage.

Cómo nos atrevemos a salirnos de nuestras caras de color. Cómo nos atrevemos a revelar la carne humana bajo la piel y sangrar sangre roja como el pueblo blanco. Se lleva una energia y valor tremenda para no asentir, para no capitular a la definición del feminismo que a la mayoría de nosotras hace invisibles. (ANZALDÚA, 1988: 222)

Ao escrever essa carta, Anzaldúa salienta a todo o momento a riqueza da vivência e da experiência das mulheres subalternizadas e que tudo isso deve ser utilizado para a construção de um outro feminismo, que rompa com os padrões eurocêntricos, hegemônicos e coloniais. Para a autora, o feminismo precisa passar por um processo de descolonização, tal qual apontam as autoras feministas decoloniais; teoria e prática devem ser construídas pelas mulheres colonizadas do Sul, de maneira a reunir a diversidade e a multiplicidade, agregando as demandas e os desafios enfrentados por essas mulheres. No trecho final dessa carta, Anzaldúa, de maneira poética, conclama as mulheres de cor e terceiro-mundistas a perceberem que a dureza de seus cotidianos pode ser a potência para a sua escrita e para o fazer feminista: "Tu piel debe ser lo suficientemente sensible para el beso más ligero y lo suficientemente gruesa para evitar las burlas. Si le vas a escupir em el ojo al mundo, asegúrate de que llevas la espalda contra el viento [...] Aunque passamos hambre no somos pobres em experiencias." (ANZALDÚA, 1988:226) 
Para Anzaldúa, para descolonizarmos as noções de feminismo e de identidade é fundamental percebermos a encruzilhada de elementos que as compõem; é impossível isolar características, demandas e identidades, visto que o ser humano é complexo e múltiplo. A categorização e a classificação são posturas colonizadoras e atuam no sentido de criar hierarquizações raciais e sociais, assim como atender às demandas e aos interesses de somente um grupo de mulheres, no que se refere ao feminismo. A autora aborda essa questão no texto La prieta (1988), também publicado no livro Este puente, mi espalda.

Mi identidad es de mujer. Quien ultraja a las mujeres me insulta a mí.

Mi identidad es de lesbiana. Quien insulta a las lesbianas me ultraja a mí.

Mi identidad es de feminista. Quien menosprecia el feminismo me desprecia a mí. (ANZALDÚA, 1988: 165)

Também nesse texto, a autora retoma a crítica ao feminismo hegemônico e branco, que se coloca de maneira salvacionista frente às mulheres não-brancas e subalternas, não permitindo que essas desfrutem do mesmo status e que tenham voz para expressarem suas demandas. No entanto, Anzaldúa aponta que a efetividade dos preconceitos impostos aos subalternos(as) não é garantida apenas pela ação do colonizador(a), mas também pela aceitação e pela ausência de resistência dos subalternos(as) e colonizados(as).

Seguramente el racismo no es solamente un fenómeno blanco [...] Es difícil liberarse del prejuicio cultural chicano en el que nací y me crié, y del sesgo cultural de la cultura anglo con que me lavaron el cérebro. Es más fácil repetir los modelos y actitudes raciales que resistirlos, especialmente los que hemos heredado por miedo y prejuicio. (ANZALDÚA, 1988: 166)

Dessa forma, é primordial para os sujeitos subalternos e colonizados superarem os modelos e as atitudes raciais impostos pelos colonizadores, desconstruindo essas categorias e desmistificando as opressões sofridas. Para autora, o ponto chave para a liberação do preconceito cultural inculcado nas cabeças colonizadas é a reconciliação com a etnicidade e com a cultura ancestral, de maneira crítica, para não aceitar opressões desses sistemas culturais também. Descolonizar os saberes e as memórias, questionar os rótulos impostos pelas práticas coloniais e aceitar-se enquanto sujeitos na encruzilhada, múltiplos e híbridos: eis o que declara a consciência mestiça de Anzaldúa, que podemos pensar como um exercício de decolonialidade e que deve ser aplicado à prática feminista. Nessa perspectiva, a autora convida homens e mulheres a se descolonizarem e atuarem como força e potência, com o intuito de superarem as múltiplas opressões: 
La lógica, el patriarcado y el heterosexual han governado y han sido los dueños por mucho tempo. Mujeres tercermundistas, lesbianas, feministas, y hombres orientados al feminismo de todos los colores se unem y se juntan para rectificar el balance. Solamente juntos podemos ser una fuerza. Nos veo como una red de espiritus emparentados, un tipo de família.

Somos los grupos raros, la gente que no pertenece a ningún sitio, ni al mundo dominante, ni completamente a nuestras propia cultura. Todos juntos abarcamos tantas opresiones. Pero la opresión abrumadora es el hecho colectivo que no cuadramos, y porque no cuadramos somos una amenaza. No todos tenemos las mismas opresiones, pero tenemos empatia y nos identificamos con las opresiones de cada uno [...] (ANZALDÚA, 1988: 168)

Portanto, para pensarmos um feminismo decolonial é necessário elaborarmos uma crítica ao feminismo hegemônico e nos afastarmos dos preconceitos culturais elaborados por ele, de maneira a construirmos autoimagens desvinculadas das representações sociais coloniais e colonizadoras. O exercício proposto por Anzaldúa é tanto externo (construir um feminismo que contemple as demandas das mulheres não-brancas e terceiro-mundistas) quanto interno (retirar de nossa psiquê todos os preconceitos culturais que foram introjetados pelas práticas coloniais). Nesse sentido, faz-se necessário construir uma nova forma de consciência, que a autora denomina de consciência mestiça e que ela aborda diretamente no livro Borderlands/La frontera: la nueva mestiza (2015).

Na primeira parte do livro, Anzaldúa revela a tirania cultural presente nas sociedades contra as mulheres não-brancas e terceiro-mundistas, que ela descreve como ativistas e invisíveis. Ela denuncia como o feminismo hegemônico e o circuito acadêmico exploram as vozes teóricas dessas mulheres, servindo-lhes de porta-vozes ou tradutoras. As mulheres subalternizadas e colonizadas precisam lutar contra essa opressão e contra a introjeção desses preconceitos culturais que as impedem de alcançar suas potencialidades. Anzaldúa denuncia as formas como essas práticas coloniais funcionam e como acabam por estruturar as psiquês das mulheres nãobrancas e terceiro-mundistas, esperando fornecer estratégias de potencialização e de organização de um feminismo descolonizado.

Para pensar os efeitos da tirania cultural sobre as psiques das mulheres subalternizadas, Anzaldúa utiliza uma figura que ela denomina de "sombra-bestia":

Dentro de mí existe una rebeldia: la sombra-bestia. Es la parte de mí que se niega a recibir órdenes de autoridades externas. Se niega a aceptar órdenes de mi voluntad consciente, amenaza la soberania de mi misma autoridad. Es esa parte de mí que odia todo tipo de limitaciones, incluso aquellas que me impongo a mí mesma. Al menor indicio de que alguien va a imponer límites a mi tempo o a mi espacio, esa parte mía patalea con ambos pies. Salta. (ANZALDÚA, 2015: 74) 
A sombra-bestia é parte da psiquê feminina que se revolta contra as imposições sociais e contra a tirania cultural. São atitudes reprovadas socialmente e que as mulheres escondem em seu íntimo, justamente pelo temor de serem repreendidas, rotuladas ou julgadas. Anzaldúa propõe a libertação da sombrabestia como uma forma de rompimento com as amarras coloniais e com a tirania cultural que se impõe às mulheres não-brancas e terceiro-mundistas. Nesse sentido, podemos compreender que permitir a atuação da sombra-bestia é construir uma outra vivência feminina, liberta da lógica colonial e com potencialidade para uma atuação efetiva em um feminismo descolonizado e construído a partir das experiências das mulheres situadas ao Sul.

Ainda sobre a tirania cultural presente nas sociedades do Norte com relação aos povos do Sul, Anzaldúa denomina como aquelas que possuem as línguas selvagens as mulheres mestiças, sobretudo as chicanas estadunidenses. Ao se questionar sobre como essas podem ser amansadas, a autora responde que elas não podem ser domadas, mas apenas cortadas. Com essa alegoria, Anzaldúa denuncia as violências sofridas pelas populações colonizadas, tanto no sentido do extermínio físico quanto simbólico. Na impossibilidade de impedir que o(a) colonizado(a) fale sua própria língua, seu próprio idioma, o(a) colonizador(a) impõe um terrorismo linguístico, transformando sua forma de comunicação em motivo de zombaria ou punição.

Mais uma vez percebemos em Anzaldúa a importância da fala e da voz. Como estratégia de potencialização de seus atos, as mulheres colonizadas, que falam uma língua selvagem, devem desafiar as imposições dos colonizadores (sejam homens ou mulheres) e utilizar sua voz e sua língua como um instrumento político. Ao falar uma língua "quebrada", híbrida e originária, as mulheres pertencentes às sociedades que sofreram intrusões coloniais têm a possibilidade de entrarem em contato com as suas origens e de descolonizar sua língua e sua voz. O exercício da decolonialidade perpassa pela retomada de uma voz e de uma língua que foram destruídas pela lógica colonial.

Por fim, para alcançar êxito na jornada de construção de um feminismo decolonial é fundamental descolonizarmos nossas identidades e aceitarmos a miscigenação (mesmo que forçada e brutal) como uma característica. A autora aponta para a impossibilidade de compartimentalizar a ideia de identidade, sendo que essa é complexa e múltipla, proveniente de diversas origens e de diversos grupos. O sujeito (o Uno) é composto de diversas características e de diversos pontos de origem (o Múltiplo), sobretudo pensando no sujeito mestiço, que carrega em si múltiplas culturas. Para Anzaldúa, ser mestiça (resultado dos processos coloniais que ocorreram ao redor do mundo) é estar com os pés em vários mundos, em várias culturas, conforme a autora aponta:

El choque de un alma atrapada entre el mundo del espíritu y el mundo de la técnica a veces la deja entullada. Acunada en uma cultura, hecha sandwich entre dos culturas, con un pie en cada una de las tres culturas y sus valores, la mestiza se somete a una lucha de 
carne y hueso, a la lucha de fronteras, a una guerra interna. Como toda la gente, solo vemos la versión de la realidade que comunica nuestra cultura. Como otras personas que tienen o viven inmersas en más de una cultura, recibimos múltiples mensajes, a menudo opuestos. La unión de dos marcos de referencia internamente coerentes, pero usualmente incompatibles, resulta en un choque cultural, una colisión de culturas. (ANZALDÚA, 2015: 139)

Com isso, a autora traz a necessidade de pensarmos uma nova forma de perceber as identidades daqueles e daquelas que pertencem às sociedades colonizadas e que passaram pelo processo de hibridismo cultural e étnico. Sendo assim, na segunda parte do livro, Anzaldúa se debruça sobre a definição do que ela denomina como consciência mestiça, que na nossa concepção pode ser uma importante contribuição para pensar a decolonialidade e o feminismo decolonial, visto que é um exercício de descolonização das identidades. Para Anzaldúa, a consciência mestiça é uma forma de descolonizar a identidade dos povos mestiços e que sofreram as intrusões coloniais

La conciencia mestiza tiene la tarea de romper con la dualidad sujeto-objeto que la mantiene prisionera y demostrar, en carne y hueso y mediante las imágenes en su obra, como se trasciende la dualidad. La solución al problema entre lar aza blanca y las de color, entre hombres y mujeres, se encuentra en la sanación de la ruptura originaria en la base misma de la vida, la cultura, las lenguas, los pensamientos. Um desarraigo masivo del pensamiento dualista en la conciencia individual y la colectiva constituye el inicio de una larga lucha, pero um que podría conducirnos, con nuestras mejores esperanzas hacia el fin de la violación, de la violencia, de la guerra. (ANZALDÚA, 2015: 140)

Apenas compreendendo a complexidade dessa identidade e transcendendo as dualidades e os binarismos é possível alcançar a consciência mestiça. Também há a necessidade de acessar a história e a memória de cada cultura, de maneira crítica, para compreender a trajetória colonial sofrida por essas sociedades. A consciência mestiça é o processo de descolonização da identidade; é desconstruir tudo aquilo que é introjetado e inculcado nas psiques colonizadas e que impedem vivências e experiências reconciliadas com a ancestralidade. Nas palavras de Anzaldúa, é liberar a sombra-bestia (que carrega em si características consideradas indesejadas pelo colonizador) e potencializar sua língua selvagem (que fala de maneira indesejada e coisas indesejadas pelo colonizador).

Dialogando com o que foi dito anteriormente, consideramos a consciência mestiça como uma expressão da decolonialidade e uma estratégia potente para o feminismo decolonial. Ainda sobre a consciência mestiça, Anzaldúa aponta para a necessidade de que as mulheres mestiças se "façam encruzilhada", libertem-se da 
vergonha de pertencer a dois ou três mundos e reconheçam essa multiplicidade como identidade: "[...] Soy un amasamiento, soy e lacto de amassar, de unir y de juntar, que ha creado una criatura de oscuridad y también una criatura de luz, la que, además cuestina las definiciones de luz y oscuridad y les da nuevos significados." (ANZALDÚA, 2015:141)

Mais uma vez, Anzaldúa indica que essa tarefa tem um duplo fazer: a luta política (mobilização e reivindicação) e a luta interna (libertação dos preconceitos culturais introjetados na psique colonizada).

La lucha es interna. Sean chicanas, indias, nativoamericanas, mojadas, mexicanas, inmigrantes latinas, gringas en el poder, gringas de clase trabajadora, negras, asiaticas, nuestras psiques se asemejan a los pueblos fronterizos habitados por la misma gente. La lucha siempre ha sido interna y se lleva a cabo en terrenos externos. La conciencia sobre nuestra situación debe proceder a los câmbios internos, los que a su vez preceden a los câmbios en la sociedade. Nada sucede en el mundo "real" si no ha aparecido antes como imagen en nuestra mente.

[...] Alver a la chicana a la luz de su historia, busco su reivindicación, mirar más allá de las ficciones de la supremacia blanca, para vernos a nosotras mismas sin disfarces y sin la falsa personalidad racial que se nos ha assignado y que hemos assumido. Busco nuestra cara de mujer, nuestros rasgos verdadeiros, lo positivo y lo negativo visto con claridade, libre de los prejuicios del domínio masculino. Busco nuevas imágenes de identidad, nuevas creencias sobre nosostras; nuestra humanidad y nuestra valia ya incuestionable. (ANZALDÚA, 2015: 147)

Com isso, compreendemos que a consciência mestiça perpassa pela superação dos preconceitos culturais e com a transformação da psique colonizada. A partir do exercício de liberar a sombra-bestia e potencializar a língua selvagem, as mulheres não-brancas e colonizadas passam a possuir instrumentos para a consolidação de um feminismo descolonizado e liberto das amarras do feminismo hegemônico, de maneira a construir sua agenda de reivindicações a partir de suas vivências e de suas experiências, de habitar um mundo múltiplo e fronteiriço.

\section{Considerações finais}

A partir do que foi exposto, podemos definir como decolonialidade o giro epistemológico proposto por Aníbal Quijano, que propicia o rompimento da lógica colonial imposta às sociedades situadas ao Sul e que essas construam formas políticas, sociais, culturais e epistemológicas libertas da colonialidade do poder. Diante disso, diversas teóricas levaram essa concepção para o campo feminista, 
forjando dessa maneira o feminismo decolonial, ou seja, um fazer feminista que critica a colonialidade de poder e de gênero, construindo sua agenda a partir das especificidades das mulheres pertencentes às sociedades que sofreram intrusões coloniais.

Nesse processo de descolonização do feminismo, a contribuição de Gloria Anzaldúa é potente. A autora foi ferrenha crítica do feminismo hegemônico e se dedicou a uma escrita que motivasse suas companheiras terceiro-mundistas a romperem com as amarras coloniais e com a tirania cultural. Os textos da autora são um chamado para que as mulheres subalternizadas percebam a beleza e a força que carregam em si mesmas, a potência de suas línguas selvagens e das sombras-bestias que vivem em suas psiques.

Anzaldúa se apresenta como a voz da nova mestiça, que se rebela contra os preconceitos culturais e se reconecta com suas origens. Esse movimento de reconciliação crítica com a ancestralidade é fundamental para a construção de uma nova identidade que possibilite uma atuação política efetiva voltada para o feminismo. Esse último deve romper de maneira contundente com as práticas coloniais e ser construído pelas e para as mulheres subalternizadas situadas ao Sul.

$\mathrm{O}$ ato de falar é considerado por Anzaldúa como um ponto chave para a insurgência das mulheres subalternizadas, na medida em que essas devem reconhecer a potência da língua selvagem (alvo de crítica e destruição por parte do colonizador) como uma estratégia para exposição de ideias, valorização de suas vivências e demarcação de suas presenças nos espaços sociais. Portanto, reencontrar a voz das mulheres subalternizadas é um exercício de fortalecimento do feminismo decolonial; fazer-se ser ouvida dentro da vertente feminista utilizando sua língua selvagem.

\section{Referências Bibliográficas}

ANZALDÚA, Gloria. (1988). Hablar en lenguas: una carta a escritoras tercermundistas. In: MORAGA, Cherrie; CASTILLO, Ana (Org.). Este puente, mi espalda. San Francisco: Ism Press, p. 219-230.

(1988). La prieta. In: MORAGA, Cherrie; CASTILLO, Ana (Org.). Este puente, mi espalda. San Francisco: Ism Press, p. 157-171

(2015). Borderlands/La frontera: la nueva mestiza. Ciudad Autónoma de México: UNAM.

BALLESTRIN, Luciana. (2013). América Latina e o giro decolonial. Revista Brasileira de Ciência Política, Brasília, n.11, p.89-117.

(2017). Feminismos subalternos. Estudos Feministas, v. 25, n. 3, p. 1035-1054. 
BIDASECA, Karina. (2010). Perturbando el texto colonial: los estudios (pos) coloniales en América Latina. Ciudad Auntónoma de Buenos Aires: SB.

(2011). "Mujeres blancas buscando salvar a mujeres color café”: desigualdade, colonialismo jurídico y feminismo postcolonial. Andamios - Revista de Investigación Social, v. 8, n. 17, p. 61-89.

(2018). La revolución será feminista o no será: la piel del arte feminista descolonial. Ciudad Autónoma de Buenos Aires: Prometeo Libros.

BIDASECA, Karina; VAZQUEZ, Vanesa. (2010). Feminismos y (des)colonialidad. Las voces de las mujeres indígenas del sur. Disponível em: <http://pdfhumanidades.com/ sites/default/files/apuntes/47\%20-\%2oBidaseca.pdf > . Acessado em: o7 de novembro de 2019 .

LUGONES, María. (2014). Rumo a um feminismo descolonial. Estudos Feministas, Florianópolis, v.22, n. 3, p. 935-952.

MOHANTY, Chandra Talpade (2008). Bajo los ojos de Occidente: Feminismo Académico y Discursos Coloniales. In: NAVAZ, Liliana Suárez; CASTILLO, Rosalva Aída Hernandez. Descolonizando el Feminismo: Teorías y Prácticas desde los Márgenes. Madrid: Cátedra, p. 112-161.

QUIJANO, Aníbal. (2009). Colonialidade do poder e Classificação Social. In: SANTOS, Boaventura de Sousa; MENESES, Maria Paula (Orgs.). Epistemologias do Sul. Coimbra: Edições Almedina, p. 73-117.

SEGATO, Rita Laura. (2016). La guerra contra las mujeres. Madrid: Traficantes de Sueños.

Recebido em 14/07/2020.

Aceito em 31/05/2021. 